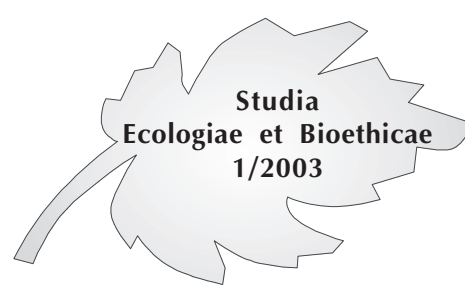

Dariusz KIEŁCZEWSKI*

\title{
O pojęciu trwałego rozwoju
}

\section{Wprowadzenie}

Celem niniejszego artykułu jest próba sprecyzowania kategorii określanej w międzynarodowej nomenklaturze jako sustainable development, a w Polsce jako ekorozwój, rozwój zrównoważony, trwaty rozwój, trwaty i zrównoważony rozwój. Autor będzie używać określenia trwaty rozwó́ zdając sobie sprawę z faktu, że wybór ten w dużej mierze jest aprioryczny.

Problem zdefiniowania kategorii trwałego rozwoju nie jest rzeczą łatwą, o czym świadczy istnienie kilkuset definicji tego pojęcia. W Polsce najczęściej kategoria ta utożsamiana jest z jej ujęciem przyrodocentrycznym skupionym na problemie zrównoważenia ekologicznego rozwoju społeczno-gospodarczego. Takie pojmowanie trwałego rozwoju jest jednak daleko idącym uproszczeniem, co zostanie wykazane $\mathrm{w}$ niniejszym artykule proponującym postrzeganie opisywanej kategorii jako całościowej koncepcji rozwojowej.

\section{Geneza trwałego rozwoju}

Można wymienić następujące elementy genezy trwałego rozwoju: element empiryczny, element polityczno- ideologiczny, element teoretyczny oraz element etyczno- filozoficzny.

Elementem empirycznym było ujawnienie się w latach sześćdziesiątych XX wieku, a następnie dalsze pogłębianie się problemów ekologicznych, społecznych i ekonomicznych.

Zlekceważenie ekologicznych podstaw rozwoju społeczno- gospodarczego doprowadziło do sytuacji, w której stan środowiska przyrodniczego stał się poważną barierą rozwojową ${ }^{1}$. Na III Sesji Zarządzającej Pro-

Uniwersytet w Białymstoku.

1 A także możliwości funkcjonowania cywilizacji ludzkiej jako takiej, przed czym przestrzegał choćby I Raport Klubu Rzymskiego (D. Meadows i in. Granice wzrostu PWE, Warszawa 1973) a po nim szereg innych powszechnie znanych publikacji. 
gramem Narodów Zjednoczonych Ochrony Środowiska (UNEP) przyjęto tezę, że społeczeństwo realizujące ideę trwałego rozwoju, to społeczeństwo uznające nadrzędność wymogów ekologicznych, które nie moga być zakłócone przez wzrost cywilizacji oraz rozwój kulturalny i gospodarczy, zdolne do samosterowania swoim rozwojem w celu utrzymania homeostazy i symbiozy z przyroda, a więc respektujące oszczędna produkcję i konsumpcje oraz wykorzystywanie odpadów, dbające o przyszłościowe konsekwencje podejmowanych działań, a więc także o potrzeby $i$ zdrowie przyszłych pokoleńn ${ }^{2}$. Lecz dziś sprowadzanie problemów trwałego rozwoju do kwestii środowiskowych jest uproszczeniem. Problemy ekologiczne uwikłane są w szereg różnorodnych problemów społecznych, których rozwiązanie warunkuje zrównoważenie gospodarki ze środowiskiem przyrodniczym, przykładowo:

- ubóstwo krajów rozwijających się opóźnia i blokuje inicjatywy ochronne $\mathrm{w}$ tych krajach i na skalę międzynarodową; $\mathrm{z}$ nierównościami ekonomicznymi i różnicami politycznymi na świecie wiążą się również takie problemy, jak zbrojenia, konflikty wojenne, terroryzm, które mogą stanowić przyczynę degradacji środowiska na wielką skalę (czego przykładem jest choćby podpalenie szybów naftowych podczas wojny w Zatoce Perskiej);

- ogromna siła lobbingu międzynarodowego kapitału również ogranicza możliwości skutecznej ochrony środowiska ze względu na nadmierną uległość państw wobec partykularnych interesów wielkich firm;

- homogenizacja kultury prowadzi do zjawiska mcdonaldyzacji polegającego na bezrefleksyjnym przejmowaniu przez społeczeństwa krajów rozwijających się stylu życia krajów wysoko rozwiniętych, przy czym najszybciej upowszechniają się zachowania najbardziej dla środowiska uciążliwe - wizyta w oskarżanym o sprzyjanie niszczeniu środowiska na wielką skalę McDonald's, czy też użytkowanie przestarzałego osobowego auta jest w krajach rozwijających się symbolem luksusu i wysokiego statusu społecznego danej osoby; wiąże się z tym również pogarda dla własnej kultury i odrzucanie a priori jej dorobku ${ }^{3}$.

Niezbędna wydaje się zatem koordynacja działań na rzecz środowiska przyrodniczego z podejmowaniem wyzwań ekonomicznych i spo-

2 Ochrona środowiska czlowieka-humanistyczne widzenie świata, w: „Prace Naukowe PKE”, tom 1, PKE, Kraków 1984.

3 Istotę takiego rozumowania celnie opisuje Wole Soyinka: Droga bita przebiegnie tędy i przyniesie nam zwyczaje miejskie. Kupimy wszystkim kobietom patelnie z aluminium, bo wyroby garncarskie sq prymitywne i antyhigieniczne. Każdy mężczyzna będzie miat prawo tylko do jednej kobiety (...). Spalimy las, zetniemy drzewa, potem będziemy pielęgnować park publiczny dla zakochanych. Codziennie będziemy drukować gazety ze zdjęciami ponętnych dziewczyn. Musimy przestać pić napój palmowy i wziqć się za picie herbaty z cukrem i mlekiem cyt. za: K. KRzYszTofeK, Cywilizacja: dwie optyki, Instytut Kultury, Warszawa 1991, s.88. 
łecznych. Z tym postulatem wiąże się polityczno-ideologiczny element genezy trwałego rozwoju. Jest to krytyka dominujących trendów w produkcji, konsumpcji i postępie technicznym jako przyczyniających się do przyspieszenia degradacji środowiska oraz krytyka dominujących polityk makroekonomicznych i sektorowych. Dostrzeżono, że działania w ochronie środowiska oparte początkowo na podejściu branżowym okazały się połowicznym sukcesem. W latach siedemdziesiątych polityka ochrony środowiska w krajach wysoko rozwiniętych oparta była na dominacji instrumentów bezpośrednich abstrahujących od kwestii kosztów ochrony środowiska. Zaowocowało to poprawą stanu środowiska w jego wielu aspektach, ale zarazem nadmiernymi kosztami i ostrożnym stosunkiem przedsiębiorstw do problematyki ekologicznej; pojawił się stereotyp głoszący, że ochrona środowiska i rozwój społeczno-gospodarczy są sobie przeciwstawne ${ }^{4}$. Ta sytuacja zmieniła się w końcu lat osiemdziesiątych $\mathrm{w}$ ochronie środowiska zaczęto na szerszą skalę wykorzystywać instrumenty ekonomiczne oraz podjęto szereg inicjatyw mających na celu racjonalizację kosztów ochrony środowiska. Podjęto też działania zmierzające do „odbranżowienia” polityki ochrony środowiska. Obecnie dąży się do rozumienia jej jako polityki prowadzonej równolegle do polityki społecznej i gospodarczej i skoordynowanej z nimi.

Trwały rozwój przestaje być utożsamiany z ochroną środowiska i z ekorozwojem, a postrzega się go jako równoczesne i skoordynowane podejmowanie wyzwań ekologicznych, społecznych i ekonomicznych w ich wzajemnym powiązaniu. Taka koncepcja trwałego rozwoju zawarta jest chociażby w najważniejszym dokumencie międzynarodowym poświęconym temu zagadnieniu, czyli w "Agendzie 21", która ujmuje trwały rozwój jako zintegrowaną sekwencję celów ekologicznych, społecznych, ekonomicznych oraz instytucjonalnych ${ }^{5}$.

Elementem teoretycznym genezy trwałego rozwoju jest krytyka tradycyjnych teorii wzrostu i wynikających z nich teorii dobrobytu ograniczających dobrobyt społeczny do konsumpcji konwencjonalnych dóbr i usług.

Najczęściej cytowana definicja trwałego rozwoju stwierdza, że jest to rozwój obecnego pokolenia nie naruszający potrzeb i możliwości rozwojowych przyszłych pokoleń. Oznacza to konieczność podjęcia kwestii długookresowej trwałości wzrostu, czego tradycyjne teorie wzrostu nie podejmują. Przede wszystkim nie pojawia się $w$ nich pytanie, czy i na ile obserwowane obecnie trendy $\mathrm{w}$ zakresie produkcji i konsumpcji mogą

$4 \quad$ Jest to powszechnie dostrzegany problem - por. np. Ekonomia środowiska i zasobów naturalnych, red. L. GABEL i in., Krupski i s-ka, Warszawa 1996, także Economy and Ecology: toward sustainable development, Kluwer Academic Publishers, Dordrecht/Boston 1989.

5 Globalny Program Dziatań na rzecz Ochrony Środowiska i Trwatego Rozwoju - Agenda 21, MOŚiZN, Warszaa 1993. 
zagrozić rozwojowi gospodarczemu w przyszłości ${ }^{6}$. Problemy ekologiczne wskazują, że takie zagrożenie, ze względu na ograniczoną pojemność środowiska przyrodniczego, istnieje. Tymczasem kwestia ta była w naukach ekonomicznych pomijana ze względu na przyjęcie założenia, że mechanizmy rynkowe są $\mathrm{w}$ stanie uchronić zasoby naturalne przed ich wyczerpaniem. Od połowy XIX wieku aż do drugiej połowy XX wieku kwestia ekonomii środowiska nie była prawie w ogóle podejmowana i rozwijana. Zmiana tej sytuacji następuje współcześnie, co ma fundamentalne znaczenie dla konstrukcji teoretycznej trwałego rozwoju i nauk ekonomicznych w ogóle.

Rozwój ekonomii środowiska zaowocował powstaniem dwóch jej koncepcji: ekonomii środowiskowej bazującej na konwencjonalnie rozumianej ekonomii i stanowiącej koncepcję ekonomizacji środowiska przyrodniczego oraz tak zwanej ekonomii ekologicznej stanowiącej w założeniu alternatywną teorię ekonomii opartą na idei ekologizacji ekonomii. ${ }^{7}$ Niezależnie od tego, $\mathrm{w}$ jakim kierunku rozwinie się ekonomia środowiska, już samo podjęcie tego problemu mocno zmieniło kształt nauk ekonomicznych. Nie tylko bowiem ekonomia ekologiczna, lecz także ekonomia środowiskowa postrzega kwestie gospodarowania odmiennie, niż konwencjonalna ekonomia właśnie ze względu na podjęcie kwestii ekologicznych uwarunkowań wzrostu gospodarczego ${ }^{8}$.

Przemiana $\mathrm{w}$ naukach ekonomicznych dokonuje się nie tylko pod wpływem rozwoju ekonomii środowiska, ale stanowi element globalnej rewolucji naukowej, którą najczęściej określa się mianem przejścia od paradygmatu mechanistyczno-deterministycznego do paradygmatu ekologicznego zwanego też ewolucyjno-dynamicznym.

Istotą podejścia mechanistyczno-deterministycznego jest przyjęcie następujących założeń poznawczych:

- warunkowość - przyczyna jest skutkiem zajścia,

- jednoznaczność - takie same przyczyny wywołują takie same skutki,

— jednostronność - skutki są zależne od przyczyny,

- redukcjonizm - rzeczywistość można poznać rozbijając ją na pojedyncze elementy i odnajdując pojedyncze przyczyny pojedynczych zjawisk ${ }^{9}$.

6 Por. wnikliwa analiza teorii wzrostu gospodarczego dokonana przez B. FIEdoRA: B. Fiedor, Podstawy badania trwatości wzrostu we wspótczesnej ekonomii, „Ekonomia i Środowisko”, 1991, nr 4, s.21-34.

7 Ecological Economics: The Science ond Management of Sustainability, ed. R. Constanza, Columbia UP, New York 1991.

8 Por. np. Podstawy ekonomii środowiska i zasobów naturalnych, red. B. Fiedor, C.H. BeCK, Warszawa 2002.

9 Por. np. S. CzAJA, Teoretyczne i metodologiczne konsekwencje wprowadzenia prawa entropii do teorii ekonomii, AE, Wrocław 1997. 
Podejście ekologiczne (ewolucyjno-dynamiczne) charakteryzuje się postrzeganiem rzeczywistości w kategoriach systemowych, globalnych i interdyscyplinarnych, przede wszystkim zaś kwestionuje redukcjonizm i jednostronność (stwierdzając, że wiele przyczyn może wyjaśniać zjawiska) oraz jednoznaczność (stwierdzając, że te same przyczyny mogą powodować różnorodne skutki) ${ }^{10}$. Mechanistyczno-deterministyczna fizyka Newtonowska postępowała w ten sposób, że rozkładała zjawiska na składniki i z ich wtasności tłumaczyła wtasności catych zjawisk. Zdawato się, że jest to naturalna metoda nauki. Tymczasem w zastosowaniu do świata atomów zawiodta. Bo ustroju atomu niepodobna w ten sposób wyttumaczyć. Stanowi on jakby całość wyższego rzędu, której niepodobna złożyć z części tak, jak się składa maszynę. Jest tak, jak gdyby nie tylko własności części wptywaty na własności całości, ale i odwrotnie, jak gdyby własności całości wptywały na własności części. Całość jest jakby celem, do którego dostosowuja się części $i^{11}$. Taka jest istota przełomu holistycznego zwrot od podejścia analitycznego, rozczłonkowującego rzeczywistość w kierunku podejścia całościowego akcentującego wewnętrzne powiązania i złożoność badanej struktury. $\mathrm{W}$ wieku XX pojawiło się wiele teorii naukowych proponujących podobne podejście do rzeczywistości; wśród nich wymienić należy przede wszystkim ekologię ${ }^{12}$ i sozologię.

Teorie odwołujące się do paradygmatu ekologicznego dążą do uwzględnienia trzech faktów odnoszących się do relacji na styku „człowiek- środowisko przyrodnicze". Z jednej strony paradygmat ten uwzględnia konieczność zachowania przyrody, uszanowania jej praw i zasad funkcjonowania jako niezbędnych elementów funkcjonowania i zachowania człowieka i jego kultury, ale też zarazem jako pewnej rzeczywistości, której wartość wewnętrzna (aksjologiczna) wynika z samego faktu, że istnieje. $\mathrm{Z}$ drugiej strony paradygmat ten uwzględnia fakt istnienia człowieka wewnątrz środowiska społecznego, stechnicyzowanego i zurbanizowanego oraz fakt, że dla wielu ludzi samorealizacja w ramach tej tylko rzeczywistości stanowi wyraz ich dążeń ${ }^{13}$. Trzeci fakt - relacje

10 Por. D. Kietczewski, Ekologia społeczna, wyd. Ekonomia i Środowisko, Białystok 2001, s. 52-54.

11 W. Tatarkiewicz, Historia filozofii, PWN Warszawa 1992 tom III. s. 277-278.

12 Warto przytoczyć w tym miejscu słynne cztery nieformalne prawa ekologii sformułowane Barry'ego Commonera:

- każda rzecz jest powiązana z innymi rzeczami,

- każda rzecz musi się gdzieś podziać,

- przyroda wie najlepiej,

- w przyrodzie nie istnieje obiad za darmo.

13 Przykładów jest wiele, między innymi subkultura klubowa i subkultura techno, które podkreślają swój związek ze środowiskiem miasta jako miejscem ich życia i samorealizacji. Kulturą miejskiego zgiełku jest także jazz. Przykładowo Miles Davis w swojej autobiografii podkreśla, że nie potrafiłby żyć w miejscu innym, niż rozświetlone, pełne ludzi i samochodów środowisko ulic miasta. 
między społeczeństwem a środowiskiem przyrodniczym są na tyle skomplikowane, że niezbędne jest komplementarne traktowanie poszczególnych nauk je opisujących, gdyż należy założyć, że przedstawiają one z konieczności uproszczony obraz tych relacji.

Tak więc rzeczywistość, w której dokonuje się egzystencja człowieka, a więc także całokształt aktywności gospodarczej, można określić jako środowisko społeczno-przyrodnicze, wewnętrznie powiązaną całość, której elementy składowe współwyznaczają się i równolegle do siebie wpływają na żyjącego w nim człowieka. Obie kategorie środowisk powinny pozostawać ze sobą w równowadze, a dominacja któregokolwiek $\mathrm{z}$ nich jest stanem niepożądanym. Istotną cechą środowiska społecznoprzyrodniczego jest to, że granica między obiema współtworzącymi je kategoriami środowisk jest płynna i staje się coraz mniej zauważalna wraz z rozwojem społeczno-gospodarczym oraz postępem nauki i techniki. Analizując procesy gospodarcze powinno się postrzegać je w perspektywie triady "gospodarka - społeczeństwo - środowisko", jako że całokształt aktywności gospodarczej dokonuje się wewnątrz środowiska społeczno-przyrodniczego.

Konwencjonalna ekonomia bazuje na założeniach paradygmatu mechanistyczno-deterministycznego, co oznacza, że nieuchronna wydaje się istotna merytoryczna i metodologiczna weryfikacja jej twierdzeń przede wszystkim w aspekcie zależności między zasobami pracy, kapitału i przyrody $^{14}$. Zapewne też nauki ekonomiczne śmielej będą wykorzystywać dorobek innych nauk, co ma już zresztą miejsce ${ }^{15}$.

Elementem etyczno-filozoficznym genezy trwałego rozwoju jest rozwijana $\mathrm{w}$ ramach tak zwanej filozofii ekologii próba nowego określenia relacji człowiek - środowisko przyrodnicze oraz podjęcie kwestii moralnego aspektu relacji „człowiek - środowisko" w ramach tak zwanej etyki ekologicznej. Postulaty filozofii i etyki ekologicznej również niosą z sobą treści wpływające na sposób rozumienia kwestii trwałego rozwoju. Składają się one na kategorię, którą można określić jako światopogląd ekologiczny alternatywny wobec światopoglądu modernistycznego przeżywającego głęboki kryzys ze względu na rozczarowanie kierunkiem rozwoju współczesnej cywilizacji najdobitniej okazane jeszcze w 1968 roku przez ruchy kontrkulturowe i ich ideologów ${ }^{16}$. Różnicę między światopoglądem ekologicznym i modernistycznym przedstawia tabela 1.

14 B. Posкrobко, Teoretyczne aspekty ekorozwoju, „Ekonomia i Środowisko” 1997 nr 1, s. 19.

15 S. Faucheux, J. F. Noel, Oekonomie naturlicher Ressourcen und der Umwelt, Metropolis Verlag, Marburg 2001.

16 Por. np. E. Fromm, Mieć czy być, wyd. Rebis, Poznań 1993. 
Tabela 1. Elementy światopoglądu modernistycznego i światopoglądu ekologicznego

\begin{tabular}{|c|c|}
\hline ŚWIATOPOGLĄD MODERNISTYCZNY & ŚWIATOPOGLĄD EKOLOGICZNY \\
\hline $\begin{array}{l}\text { Antropocentryzm: } \\
\text { — człowiek jest panem przyrody, której } \\
\text { wartość wynika z jej użyteczności dla } \\
\text { człowieka, } \\
\text { — intensywna eksploatacja przyrody jest } \\
\text { uzasadniona potrzebami człowieka }\end{array}$ & $\begin{array}{l}\text { Etyka ekologiczna } \\
\text { - istnieje moralny problem stosunku } \\
\text { człowieka do świata przyrody }\end{array}$ \\
\hline $\begin{array}{l}\text { Technokratyzm: } \\
\text { - rozwój techniki nie podlega krytycz- } \\
\text { nej ocenie, } \\
\text { - istnieje przymus innowacyjny, } \\
\text { - co technika zniszczyła, technika na- } \\
\text { prawi }\end{array}$ & $\begin{array}{l}\text { Odpowiedzialność za technikę: } \\
\text { — technika stwarza problemy ekolo- } \\
\text { giczne i egzystencjalne, a wobec nie- } \\
\text { których własnych tworów może być } \\
\text { bezradna, } \\
\text { - należy stworzyć moralne zasady ko- } \\
\text { rzystania z techniki }\end{array}$ \\
\hline $\begin{array}{l}\text { Ekonomizm: } \\
\text { - pomyślność narodów mierzy się } \\
\text { wzrostem wysokości dochodów, } \\
\text { - praca służy bogactwu, } \\
\text { - konsumpcjonizm jest drogą samore- } \\
\text { alizacji }\end{array}$ & $\begin{array}{l}\text { Jakość życia: } \\
\text { - } \text { gospodarowanie ma służyć zapewnie- } \\
\text { niu wszechstronnego dobrobytu, } \\
\text { - } \text { praca służy samorealizacji, } \\
\text { - } \\
\text { nie samym chlebem żyje człowiek }\end{array}$ \\
\hline $\begin{array}{l}\text { Paradygmat mechanistyczno-determini- } \\
\text { styczny poznania naukowego }\end{array}$ & $\begin{array}{c}\text { Paradygmat ekologiczny (ewolucyjno- } \\
\text {-dynamiczny) poznania naukowego }\end{array}$ \\
\hline
\end{tabular}

Źródło: opracowanie własne

Przemiany światopoglądowe, czyli przemiany w świadomości społecznej z pewnością wpływają na rozumienie i kształt trwałego rozwoju, ponieważ proces gospodarczy odbywa się nie tyle w biurach i halach fabrycznych, ile w psychice gospodarującego człowieka.

\section{Istota trwałego rozwoju}

Trwały rozwój początkowo opisywano wyłącznie w kategoriach ekonomicznych i rozumiano go jako taki rozwój społeczno-gospodarczy, który uwzględnia $w$ procesach gospodarowania uwarunkowania ekologiczne. Chodziło o utrzymanie parametrów środowiska przyrodniczego zapewniających ochronę człowieka i ważnych dla niego ekosystemów przed biologiczną degradacją i zagładą przy zachowaniu dotychczasowych celów rozwoju - stałego wzrostu dobrobytu, komfortu życia, kon- 
sumpcji itp. oraz krótkoterminowej perspektywy ${ }^{17}$. Potem pojęcie to było rozszerzane i uzupełniane. W raporcie Specjalnej Komisji ONZ „Środowisko i Rozwój", opracowanym w 1987 r. pod kierunkiem G.H.Brundtland oznaczało już taki rozwój społeczno-gospodarczy, który zapewni zaspokojenie potrzeb współczesnego społeczeństwa bez naruszania możliwości zaspokojenia potrzeb przyszłych pokoleń. $W$ definicji tej zawarta jest więc idea długookresowego pojmowania trwałego rozwoju, zatem także trwałej istotnej jakościowo zmiany sposobu funkcjonowania gospodarki. W latach dziewięćdziesiątych upowszechniła się jeszcze szersza interpretacja: ekospoteczny model rozwoju, nowa wizja społeczna, w której utrzymanie dynamicznej równowagi biosfery (jako warunek przetrwania ludzkości) staje się naczelna zasada określająca i porządkująca wszelka dziatalność (...). Ujmowany z takiej perspektywy ekorozwój [czyli trwały rozwój - przyp. aut.] jest to taki rozwój cywilizacyjny, który w dtugiej perspektywie historycznej jest zarazem dopuszczalny ekologicznie, pożądany aksjologicznie i akceptowany społecznie oraz efektywny (racjonalny) ekonomicznie ${ }^{18}$. Tak rozumiany trwały rozwój odnosi się do całokształtu problemów cywilizacyjnych ludzkości stanowiąc tym samym ideę społeczno-filozoficzną.

Można wymienić trzy sposoby rozumienia trwałego rozwoju:

- jako ideę społeczno-filozoficzną,

- jako nowoczesny kierunek rozwoju gospodarki,

- jako nowy kierunek badań naukowych ${ }^{19}$.

Trwały rozwój rozumiany jako idea społeczno-filozoficzna ujmowany jest zazwyczaj nie tyle w kategoriach "gospodarka - społeczeństwo środowisko", ile w kategorii bardziej ogólnie rozumianej relacji „cywilizacja - środowisko" (,antroposfera - środowisko" $)^{20}$. W tak pojętej idei zawiera się postulat harmonizowania powiązań między cywilizacyjną aktywnością człowieka a środowiskiem przyrodniczym. Cywilizacja (antroposfera) charakteryzuje się wielką złożonością, współtworzą ją bowiem następujące elementy:

- nauka, czyli sfera służąca dogłębnemu poznaniu wszystkich dziedzin, w których występuje życie i człowiek;

- technika, czyli sfera praktycznego wykorzystania poznania naukowego oraz świadectwo praktycznej działalności człowieka;

- gospodarka, czyli sfera aktywności ekonomicznej człowieka;

17 Por. J. Winpenny, Wartość środowiska, PWE, Warszawa 1996, s. 19-22; także S. FacheuX, J.F. NoEl, Oekonomie... op.cit. p.IV.

18 Z. Hull, Problemy filozofii ekologii, w: Wprowadzenie do filozoficznych problemów ekologii, red. A. PAPUZIŃsKI, AB, Bydgoszcz 1999, s. 92- 93.

19 B. Posкroвко, Teoretyczne aspekty ekorozwoju, „Ekonomia i Środowisko” 1997 nr 1, s. 10-11.

20 J.M. DoŁĘGA, Człowiek w zagrożonym środowisku, wyd. ATK, Warszawa 1998; D. KIEŁCZEWSKI, Ekologia spoteczna, Wyd. Ekonomia i Środowisko, Białystok 2001. 
- struktura społeczna, czyli zróżnicowanie społeczeństwa pod względem płci, wieku, narodowości, rasy, wykształcenia, tradycji kulturowej oraz relacje między poszczególnymi grupami społecznymi;

- polityka, czyli sfera podejmowania decyzji dotyczących kształtowania poszczególnych sfer antroposfery;

- kultura materialna, czyli sfera działalności człowieka obejmująca wytwory ludzkie w dziedzinie słowa, rzeźby, malarstwa, muzyki, architektury i innych form twórczości;

- kultura duchowa, czyli sfera wartości symbolicznych oraz wzorów i norm postępowania: etycznych, religijnych, wychowawczych, obyczajowych, prawnych; w jej skład wchodzą także kategorie estetyczne i inne wartości duchowe;

- kultura masowa, czyli ogół jednolitych form masowego uczestnictwa w kulturze oraz jednolitych wytworów kultury przeznaczonych dla masowego odbiorcy.

O trwałym rozwoju można mówić wtedy, gdy wszelkie procesy w antroposferze są zharmonizowane $\mathrm{z}$ procesami zachodzącymi $\mathrm{w}$ środowisku przyrodniczym, dzięki czemu utrzymuje się między nimi utrwalona hoemostaza. W sensie idei społeczno-filozoficznej jest więc trwały rozwój złożonym procesem cywilizacyjnym obejmującym koewolucję ze środowiskiem przyrodniczym wszelkich elementów składowych antroposfery - przemiany $\mathrm{w}$ nauce $\mathrm{i}$ technice, przemiany $\mathrm{w}$ gospodarce, strukturze społecznej, polityce, kulturze materialnej, duchowej i masowej ${ }^{21}$.

Najczęściej trwały rozwój jest definiowany w kontekście drugiego sposobu jego rozumienia, czyli jako nowoczesnego kierunku rozwoju gospodarki. W polskiej praktyce językowej wprowadzone zostały trzy interpretacje eksponujące następujące cechy sustainable development: zrównoważenie, trwałość i samopodtrzymywanie się rozwoju ${ }^{22}$.

Trwały i zrównoważony rozwój jest więc zrównoważony zgodnie $\mathrm{z}$ definicją Pearce'a i Turnera - polega on na maksymalizacji korzyści netto z rozwoju ekonomicznego, chroniąc jednocześnie oraz zapewniając odtwarzanie się użyteczności i jakości zasobów naturalnych w dtugim okresie. Rozwój gospodarczy musi wówczas oznaczać nie tylko wzrost dochodów per capita, ale także poprawe innych elementów dobrobytu spotecznego. Musi on obejmować również niezbędne zmiany strukturalne $w$ gospodarce, jak $i$ w catym społeczeństwie ${ }^{23}$. Można wymienić następujące wymiary zrównoważenia rozwoju:

- wymiar ekologiczny: maksymalizowane są korzyści netto z rozwoju gospodarczego przy jednoczesnym zachowaniu użyteczności i jakości

21 Szerzej patrz: D. KIEєCZEWSKI, Ekologia...op. cit. s. 146-149.

22 Wskaźniki ekorozwoju, red. T. Borys, wyd. Ekonomia i Środowisko, Białystok 1999, s. 69-78.

23 D. Pearce, R.K. Turner, Economics of natural resources and the environment, Harvester Wheatsheaf, New York 1990, s. 11. 
zasobów naturalnych w nieograniczonej perspektywie czasowej, co oznacza, że materialny poziom produkcji i konsumpcji jest ograniczony do poziomu akceptowalnego z punktu widzenia potrzeby zachowania jakości środowiska (ekorozwój);

- wymiar ekonomiczny: nie pogarsza się funkcjonowanie czynników rozwoju oraz nie zmniejsza się żaden element składowy wektora celów ekonomicznych związanych z procesem rozwoju;

- wymiar socjalny: dobrobyt społeczny jest względnie równo rozłożony, co oznacza, że dla wszystkich ludzi niezależnie od czasu i przestrzeni dostępne są przynajmniej dobra społecznie pożądane;

- wymiar psychologiczny: wzrostowi dochodów per capita towarzyszy poprawa w zakresie innych elementów współtworzących dobrobyt społeczny;

- wymiar demograficzny: procesy demograficzne są dostosowane do procesów ekologicznych i pojemności środowiska oraz nie powodują istotnych zaburzeń w funkcjonowaniu społeczeństwa i gospodarki (przeciwdziałanie skutkom eksplozji i implozji demograficznej);

- wymiar intertemporalny - zaspokajanie potrzeb obecnego pokolenia nie wiąże się $\mathrm{z}$ uszczerbkiem możliwości zaspokojenia analogicznych potrzeb przyszłych pokoleń.

Trwały rozwój jest trwały - zwykle to tautologiczne stwierdzenie utożsamia się z kwestią trwałości kapitału przyrody ${ }^{24}$. Lecz kategorię trwałego rozwoju raczej należy rozumieć szerzej - utożsamiać z nieograniczonym horyzontem czasowym wzrostu dobrobytu społecznego. Trwałość kapitału przyrody ma tu znaczenie instrumentalne; chodzi bowiem o trwałość wszystkich możliwych czynników wzrostu dobrobytu, na których rolę $\mathrm{w}$ różnorodnym zresztą stopniu wskazują poszczególne teorie wzrostu gospodarczego:

- równomierność wzrostu gospodarczego podkreślana w neoklasycznej teorii wzrostu gospodarczego;

- inwestycje w kapitał ludzki, wynalazki i innowacje, których rolę podkreśla teoria wzrostu endogenicznego;

- trwałość wykorzystywania kapitału przyrody, co podkreśla się w koncepcji trwałego rozwoju;

- równowaga między materialnymi i niematerialnymi składowymi dobrobytu społecznego ${ }^{25}$.

Takie rozumienie trwałości zawarte jest $\mathrm{w}$ najprostszej i najpopularniejszej definicji trwałego rozwoju zaproponowanej przez komisję Gro Harlem Bruntland oraz konsekwentnie rozwija się je w dokumencie

24 Industrial Metabolism. Restructuring for Sustainable Development, S.U. Ayres, E. U. Simmons (ed.), Paris-Tokyo-New York, s. 33-41.

25 Por. Wskaźniki... op. cit., s. 75-77; także K. MEREdyK, „Optimum. Studia Ekonomiczne” 
Agenda 21, który poświęcony jest głównie temu, jak przeciwdziałać ubóstwu oraz innym problemom rozwojowym nie zaciągając długu wobec przyszłych pokoleńn ${ }^{26}$.

Można zidentyfikować cztery zasady trwałości kapitału: słabą, wrażliwą, mocną i restrykcyjną ${ }^{27}$. Słaba zasada trwałości kapitału polega na zachowaniu wielkości całkowitego kapitału bez względu na jego strukturę, na którą składają się kapitał przyrodniczy, wytworzony przez człowieka, społeczny i ludzki; zakłada się, że różne rodzaje kapitału są doskonałymi substytutami, przynajmniej w granicach wyznaczonych bieżącym poziomem działalności gospodarczej i istniejącymi w danym momencie zasobami. Wrażliwa zasada trwałości kapitału polega na tym, że wymaga się aby poza zachowaniem całkowitej wielkości kapitału została zachowana odpowiednia relacja między składowymi kapitału; kapitał wytworzony przez człowieka i kapitał przyrodniczy mogą być substytutami tylko w określonych granicach. Mocna zasada trwałości kapitału polega na tym, że zachowuje się z osobna każdy rodzaj kapitału, co wynika z założenia, że kapitał przyrodniczy i kapitał wytworzony przez człowieka są komplementarne, a nie substytucyjne. Restrykcyjna zasad trwałości kapitału polega na zakazie uszczuplania któregokolwiek z zasobów - zasoby nieodnawialne nie mogłyby być w ogóle eksploatowane, a w przypadku zasobów odnawialnych dopuszczalne jest tylko zużycie tej części, która jest jego rocznym przyrostem.

W literaturze poświęconej kwestiom trwałego rozwoju proponuje się różne ujęcia trwałości kapitału, stąd można mówić co najmniej o trzech ujęciach trwałego rozwoju ${ }^{28}$ - ekskluzjonistycznym, inkluzjonistycznym oraz ekologicznym.

Ekskluzjonizm i inkluzjonizm stanowią przeciwstawne interpretacje relacji "gospodarka - środowisko" w kategoriach paradygmatu mechanistyczno-deterministycznego.

Ekskluzjoniści głoszą, że rzeczywistość społeczna jest niezależna od przyrodniczej ${ }^{29}$. Człowiek, twierdzą oni, może w pełni kontrolować zjawiska przyrodnicze na całej kuli ziemskiej określając parametry dla poszczególnych systemów przyrodniczych i społecznych. Ekskluzjoniści sprowadzają kwestię trwałości kapitału przyrody do słabej zasady kapitału stwierdzając, że istnieje doskonała substytucja zasobów, a także, że współczesny problem degradacji środowiska przyrodniczego stanowi jeden z wielu i historycznie nieistotny problem cywilizacyjny, co starają się

26 Na co słusznie zwraca uwagę: T. ŻyLIcz, Rola nauki w polityce trwałego rozwoju, „Ekonomia i Środowisko", $2002 \mathrm{nr}$ 2, s. 57-58.

27 B. Fiedor, Podstawy badania trwatości...op.cit. s. 27-28.

28 Autor przyjmuje tu klasyfikację zaproponowaną przez Jana Grzesicę w publikacji: J. GRzeSICA, Ochrona naturalnego środowiska człowieka - problem teologiczno-moralny, Ks. Św. Jacka, Katowice 1983

29 Tamże, s. 51-60. 
wykazać bazując na koncepcji tak zwanej krzywej Kuznetsa obrazującej relacje między wzrostem gospodarczym a degradacją środowiska i sugerującej, że wraz ze wzrostem gospodarczym problemy ekologiczne poszczególnych krajów stopniowo są rozwiązywane ${ }^{30}$.

Inkluzjoniści głoszą poglądy przeciwstawne, których istotę stanowi twierdzenie, że dla wyjaśniania zjawisk społecznych wystarczą zmienne biologiczne. Kultura jest w tym ujęciu jedynie aspektem społecznego funkcjonowania człowieka w świecie, który jest całkowicie wyjaśnialny za pomocą czynników biologicznych. Determinanty ludzkich zachowań mają być określane wyłącznie przez zmienne biologiczne; nie uwzględnia więc zależności społeczno-kulturowych. W swej skrajnej postaci inkluzjonizm nie dostrzega istotnych jakościowych różnic między człowiekiem a innymi istotami biologicznymi. W konsekwencji inkluzjoniści opowiadają się po stronie mocnej zasady trwałości kapitału przyrody, a najbardziej radykalni, zwolennicy tak zwanej ekologii głębokiej, nawet po stronie restrykcyjnej zasady trwałości kapitału przyrody. Jest to uzasadniane specyficznie rozumianą etyką biocentryczną opartą na idei równości biotycznej zakładającej, że wszystkie istoty żywe mają jednakowe prawo do życia, więc człowiek nie ma prawa unicestwiać jakiejkolwiek formy życia z wyjątkiem sytuacji, gdy zaspokajane są jego żywotne potrzeby. Przy czym zasada ta odnosi się również do zasobów przyrody nieożywionej. ${ }^{31}$

Z punktu widzenia paradygmatu ekologicznego (będącego faktyczną metodologiczną podstawą teorii trwałego rozwoju) jednoznaczne określenie zasady trwałości kapitału wydaje się nierealne ze względu na niepewność i ryzyko gospodarowania w środowisku. Stosowanie tych zasad powinno być elastyczne - nie można mówić o jednej tylko zasadzie w stosunku do całości tego kapitału. Takie podejście reprezentuje również autor opracowania.

W przypadku zasobów nieodnawialnych naturalnie narzuca się słaba zasada trwałości kapitału, czyli przyjęcie zasady, że zasoby te z pewnością zostaną wyczerpane lub zastąpione odnawialnymi substytutami. Chodzi jedynie o to, by zgodnie z koncepcją zaproponowaną przez Hottelinga ${ }^{32}$, stopa ich eksploatacji uwzględniała rentę przysługującą przyszłym pokoleniom. Oznacza to, że skala eksploatacji tych zasobów powinna być taka, by możliwe było zachowanie odpowiedniej rezerwy zasobów dla przyszłych pokoleń lub zapewniona możliwość zastąpienia ich odnawialnymi substytutami w taki sposób, by nie nastąpiły znaczące zaburzenia w funk-

30 O krzywej Kuznetsa: E. J. Yanarella, R.S. Levine, Does sustainable development lead to sustainability?, „Futures” $1992 \mathrm{nr} 8$.

31 B. Devall, G. Sessions, Ekologia głęboka, wyd. Pusty Obłok, Warszawa 1996, s. 99.

32 H. Hotteling, The Economics of Exhausible Resources, „Journal of Political Economy” nr 39, 1931, s. 137-175. 
cjonowaniu gospodarki. Potrzeba zachowania rezerw zasobów dla przyszłych pokoleń oznacza też, że słabą trwałość uzupełnia w niektórych sytuacjach wrażliwa zasada trwałości kapitału. Kryterium słabej trwałości kapitału i wzrostu zaproponował Hammond $w$ formie wzoru:

\section{$\wedge \mathbf{W}($ ER) $\mathbf{t}+\mathbf{I} \mathbf{t}>\mathbf{0}$,}

gdzie $\wedge W(E R) t$ oznacza spadek wartości zasobów nieodnawialnych $\mathrm{w}$ określonym czasie, a I t oznacza wartość inwestycji powiększających zasób kapitału trwałego w tym samym okresie ${ }^{33}$.

Natomiast w przypadku zasobów odnawialnych raczej mowa o mocnej, a w przypadku niektórych także restrykcyjnej zasadzie trwałości kapitału. Jest to uzasadnione między innymi przez fakt, że wszystkie rodzaje zasobów odnawialnych współtworzą zasób o fundamentalnym znaczeniu dla funkcjonowania środowiska i gospodarki, którym jest różnorodność biologiczna. Poza tym mocną zasadą trwałości kapitału w pewnym zakresie staje się też zasadą spontanicznie przyjmowaną przez społeczeństwo - zwraca się uwagę, że rozwój moralności ekologicznej zmierza $\mathrm{w}$ kierunku jej rozumienia nieantropocentrycznego, to znaczy uznania istnienia poszczególnych gatunków roślin i zwierząt jako wartości samej w sobie. Takie rozumienie etyki ekologicznej utrwala się w społeczeństwie, choć niewątpliwie $\mathrm{w}$ największym stopniu odnosi się ono do tak zwanych gatunków charyzmatycznych, to znaczy tych, którym człowiek przypisuje szczególne atrybuty symboliczne, estetyczne, kulturowe itp., co ogranicza rolę tych motywacji ${ }^{34}$.

Samopodtrzymywanie się rozwoju oznacza natomiast taki kształt rozwoju, w którym minimalizowane jest ryzyko wewnętrznych zaburzeń ograniczających lub uniemożliwiających dalszy rozwój. Chodzi o to, by w gospodarce nie uruchamiały się mechanizmy prowadzące do jej autodestrukcji.

Trzeci sposób rozumienia trwałego rozwoju to kierunek badań naukowych. Niewątpliwie istnieje konieczność opracowania teoretycznych podstaw trwałego rozwoju i jest to zadanie złożone. Wynika to ze złożoności i interdyscyplinarności tej problematyki oraz z cech trwałego rozwoju:

- charakteru normatywnego: u podstaw idei trwałego rozwoju znajduje się pewien wybór wartości i cele polityczne;

- holistycznego (systemowego) charakteru zjawisk ujmowanych w ramach trwałego rozwoju: łącznego traktowanie gospodarki, społeczeń-

33 A. Hammond, Environmental Indicators: A Sistematic Approach to Measuring and Reporting on Environmental Policy Performance in the Context of Sustainable Development, World Resources Institute, washington 1995.

34 Taki pogląd głosi większość autorów opisujących ewolucję praktycznej moralności środowiskowej, Por. np. M. Andreas-Grisebach, Eine Ethik fue die Natur, Fischer Alternativ, Frankfurt am Mein 1995, A. GaUdie, Mensch und Umwelt, UP, Berlin-Oxford-Heidelberg 1994, A. Winkler, B. Voller, European Consumers and Environmentalism, Gfk Verbraucherforschung, Berlin 1992.; ed. II 1999. 
stwa i środowiska, a więc także ładu ekonomicznego, przestrzennego, demograficznego, politycznego i etycznego;

- interdyscyplinarności podejmowanej problematyki;

- konieczności długookresowego ujęcia, co sprawia wielkie trudności, gdyż jest obciążone olbrzymim balastem niepewności i ryzyka: nieznane są kierunki rozwoju nauki i techniki, potrzeby przyszłych pokoleń, poważnym wyzwaniem jest także naturalna skłonność producentów i konsumentów do preferowania własnych celów i preferencji w stosunku do celów i preferencji następnych generacji itp.

Wynika $\mathrm{z}$ tego, że teoria trwałego rozwoju raczej nie powinna zamykać się $\mathrm{w}$ ramach jednej nauki. Niezbędny zasób wiedzy muszą dostarczyć nauki społeczne (w tym ekonomiczne), przyrodnicze, medyczne, prawne, techniczne; żadna $\mathrm{z}$ nich nie daje pełnego obrazu zjawisk wyznaczających merytoryczny zakres tej teorii. Pojawia się jednak wątpliwość o relację tych nauk wobec siebie. Można wymienić w tym aspekcie trzy poglądy. Pierwszy z nich wyraża się $\mathrm{w}$ przekonaniu, że nie chodzi o jedna, ale o wiele teorii trwałego rozwoju rozwijanych $w$ ramach poszczególnych nauk przyrodniczych i społecznych. Skoro więc nieuchronna jest specjalizacja naukowa, to nieuchronny jest również podział zadań odnośnie teorii trwałego rozwoju. Analizuje się więc poszczególne kwestie $\mathrm{w}$ ramach poszczególnych dyscyplin, a następnie scala. Przeciwstawny pogląd to próba skonstruowania metanauki analogicznej do rozwijanej swego czasu sozologii ${ }^{35}$. Jej przedmiotem byłyby zagadnienia trwałego rozwoju. Integrowałaby ona metodologię różnych nauk. Trzeci, kompromisowy pogląd, w kierunku którego skłania się także autor tej publikacji, przyjmuje, że możliwe i potrzebne jest stworzenie nie tyle metanauki, ile metateorii trwałego rozwoju, która koordynowałaby badania prowadzone $\mathrm{w}$ ramach poszczególnych teorii trwałego rozwoju - chodzi o przyjęcie pewnych założeń metafizycznych i metodologicznych wspólnych dla nich ${ }^{36}$. Metateoria trwałego rozwoju pozwoliłaby na skoordynowanie badań prowadzonych $\mathrm{w}$ ramach poszczególnych dyscyplin - metodologia zostałaby ujednolicona, poszczególne zagadnienia byłyby podejmowane $\mathrm{w}$ ich wzajemnym interdyscyplinarnym związku zgodnie z założeniami teorii synergetyki.

Wydaje się zatem, że teoria trwałego rozwoju powinna funkcjonować w dwóch wymiarach: jako metateoria wyznaczająca najbardziej podstawo-

35 O sozologii: J.M. DoŁęGA, Człowiek w zagrożonym środowisku, wyd. ATK, Warszawa 1997.

36 Jedną z propozycji takiej metateorii jest koncepcja ekologii społecznej przedstawiona przez autora tej pracy w jednej z jego wcześniejszych publikacji „Ekologia społeczna”. Przy czym ekologia społeczna rozumiana jest jako dziedzina wiedzy mająca na celu poznanie związków i zależności występujących w relacji między antroposferą a środowiskiem przyrodniczym oraz modelowanie tych relacji w kierunku osiągnięcia i utrwalenia równowagi między nimi. Tak rozumiana ekologia społeczna bada oraz ocenia aktualne i potencjalne formy działalności człowieka w środowisku przyrodniczym oraz postawy wobec niego zalecając te, które pozostają w zgodzie z właściwościami przyrody oraz z podstawami trwania i rozwoju cywilizacji 
we i ogólne założenia teoretyczne oraz teorie trwałego rozwoju rozwijane w ramach poszczególnych dyscyplin naukowych. Niezależne badania w ramach poszczególnych dyscyplin prowadziłyby do trudności w scaleniu wniosków i ich aplikacji, poza tym obciążone byłyby zapewne uproszczeniami wynikającymi z redukcjonistycznej metodologii charakterystycznej dla tradycyjnie rozumianych dyscyplin naukowych, a związki i zależności między dyscyplinami zapewne zignorowane lub zdeformowane poznawczo. Metanauka jako podstawa trwałego rozwoju obciążona zaś jest błędem metodologicznym określonym przez V. Hoessle jako „wszystkość" ${ }^{\prime 7}$ struktura współczesnej nauki jest zbyt skomplikowana i zbyt rozbudowana, by takie rozwiązanie mogło dać zadowalające efekty poznawcze.

Za najważniejsze wyzwanie wobec ekonomicznej teorii trwałego rozwoju uznawane jest przywrócenie odpowiedniej proporcji $\mathrm{w}$ badaniach ekonomicznych dotyczących poszczególnych zasobów gospodarczych. Oznacza to, że teoria ta poświęca szczególnie wiele uwagi ekonomii środowiska oraz problemowi przyrodniczych podstaw gospodarowania jako zagadnieniami niedostatecznie poznanymi i opisanymi ${ }^{38}$.

\section{Cele trwałego rozwoju}

Cele trwałego rozwoju, analogicznie do sposobów jego rozumienia, ujmuje się w sensie cywilizacyjnym, ekonomicznym oraz teoretycznym.

Najwcześniejsza i najbardziej znana klasyfikacja celów trwałego rozwoju sporządzona przez Davida Pearce'a umieszcza je na poziomie cywilizacyjnym. Są to:

- sprawiedliwość wewnątrzpokoleniowa - dążenie do zmniejszenia różnic w poziomie życia między Północą a Południem, wykorzenienia ubóstwa, analfabetyzmu, chorób, zapewnienia ochrony zdrowia i życia oraz dostępu do oświaty wszystkim ludziom na Ziemi, ochrony różnorodności kulturowej,

- sprawiedliwość międzypokoleniowa - zapewnienie możliwości rozwoju społeczno-gospodarczego przyszłym generacjom,

- sprawiedliwość wobec istot pozaludzkich - zapewnienie przetrwania gatunkom flory i fauny, podporządkowanie działań wzorcom i prawom przyrody na terenach nie zdominowanych przez człowieka,

ludzkiej. Tak pojętej ekologii społecznej nie należy przy tym utożsamiać z komunistyczną utopią zaproponowaną przez Murray'a Bookchina sprowadzającą wszystkie problemy na styku „społeczeństwo - gospodarka - przyroda” do dysfunkcji współczesnego sposobu organizacji społeczeństwa i naiwnie postrzegającą anarchokomunistyczną organizację społeczną jako antidotum na wszelkie problemy cywilizacyjne.

37 V. Hoessle, Philosophie....op. cit. s. 57.

38 В. Роsкrobкo, Teoretyczne... op. cit., s. 19-20. 
ochrona przed pustoszeniem środowiska przyrodniczego powodowanych przez działania wojenne, terroryzm ${ }^{39}$.

Charakterystyczna dla tej klasyfikacji jest postawa nieantropocentryczna. Przetrwanie gatunków flory i fauny jest w niej uznane za cel sam w sobie, co jest zgodne $\mathrm{z}$ charakterem upowszechniającej się $\mathrm{w}$ ostatnich latach etyki ekologicznej. Trzeba jednak $\mathrm{w}$ tym miejscu podkreślić, że $\mathrm{w}$ ciągu lat dziewięćdziesiątych rozumienie celów trwałego rozwoju przez Perce'a stało się bardziej „zachowawcze" - autor ten mówi obecnie raczej wyłącznie o sprawiedliwości wewnątrz - i międzypokolenioweje ${ }^{40}$ postrzegając trwały rozwój $\mathrm{w}$ kategoriach antropocentrycznych zgodnie z duchem większości dokumentów międzynarodowych poświęconych problemowi. Wydaje się, że tak defensywna postawa jest niepotrzebna. Hasła w rodzaju „różnorodność biologiczna”, czy też „mocna zasad trwałości kapitału” sprowadzające potrzebę ochrony istnień pozaludzkich do czysto użytecznościowych uzasadnień nie wyczerpują spectrum rzeczywistych uzasadnień tej ochrony i są sprzeczne z faktycznie uznawanym systemem wartości wyrażającym się poprzez istniejącą w praktyce etykę ekologiczną. Przykładowo w badaniach Gaudiego prowadzonych w latach 90. w Niemczech i Wielkiej Brytanii ponad $80 \%$ respondentów uzasadniało potrzebę ochrony gatunków roślinnych i zwierzęcych wartością ich istnienia, a więc uzasadnieniem nieantropocentrycznym ${ }^{41}$. Uznanie sprawiedliwości wobec istot pozaludzkich za odrębny cel trwałego rozwoju wydaje się więc uzasadnione z punktu widzenia postrzegania etyki przez ludzi oraz na podstawie faktycznie istniejącej sytuacji społecznej $\mathrm{w}$ aspekcie świadomości i etyki ekologicznej. Należy pamiętać, że sposób postrzegania relacji etycznych przez człowieka jest bardzo prosty - przykładowo określony stosunek człowieka do zwierzęcia wypływający z jego zachowania funkcjonuje w ramach konkretnej relacji ",człowiek - zwierzę", a nie abstrakcyjnego w tym przypadku stosunku ",człowiek - człowiek”; dana osoba jest wobec zwierzęcia okrutna lub postępuje wobec niego humanitarnie dlatego, że uważa takie postępowanie za słuszne, a nie dlatego, że ma przez to wyrażać swój stosunek do innych ludzi. Uzasadnianie potrzeby etyki ekologicznej wyłącznie argumentacją antropocentryczną niepotrzebnie komplikuje relacje etyczne oraz może stanowić pretekst do nadużywania prawa człowieka do ingerencji w środowisko przyrodnicze. Niezdolność istot pozaludzkich do odwzajemnienia określonego zachowania nie stanowi tu przeszkody - obowiązek moralny jest odczuwany jednostronnie niezależnie od tego, czy podmiot, wobec którego ten obowiązek istnieje, odwzajemnia go i czy w ogóle jest go w stanie odwzajemnić.

39 D. Pearce, Foundations of an Ecological Economics, „Ecological Modelling” 1987, nr 38, s. 9-18.

40 Por. np. D. Pearce, Sustainable consumption throgh economic instruments, Norway Simposium on Sustainable Consumption, Oslo 1994.

41 A. Gaudie, Mensch und Umwelt, UP, Berlin-Oxford-Heidelberg 1994. 
Przyjęcie powyższych cywilizacyjnych celów trwałego i zrównoważonego rozwoju powoduje następujące postrzeganie jego celów ekonomicznych.

Celem rozwoju społeczno-gospodarczego jest wzrost dobrobytu dotychczas utożsamiany ze wzrostem dochodów. Za cel trwałego rozwoju również można uznać wzrost dobrobytu, lecz rozumiany szerzej. Za cel podstawowy można uznać osiągnięcie trwałego i zrównoważonego względnie równo rozdzielonego dobrobytu społecznego i indywidualnego, które zależy nie tylko od konsumpcji dóbr i usług, lecz także od ekologicznych warunków życia.

Stąd wypływa wiązka celów trwałego rozwoju, które można określić jako cele drugiego stopnia. Dotyczą one zapewnienia trwałości warunków osiągnięcia w perspektywie długookresowej zrównoważonego dobrobytu. Należą do nich:

- cele ekologiczne: zachowanie różnorodności biologicznej, integralności systemów przyrodniczych, produkcji biologicznej, czy też, mówiąc inaczej, respektowanie celu sprawiedliwości wobec istot pozaludzkich;

- cele ekonomiczne: dalszy wzrost materialnego dobrobytu, wzrost dostępności użytecznych dóbr i usług, stabilny wzrost gospodarczy;

- cele społeczne: zapewnienie dostępu do dóbr społecznie pożądanych, zaspokojenie podstawowych potrzeb materialnych (ograniczanie biedy), zachowanie różnorodności kulturowej, zapewnienie trwałości instytucjonalnej, gwarancje sprawiedliwości społecznej i współudziału w życiu społecznym i politycznym;

- cele psychologiczne: zapewnienie zrównoważenia między dobrobytem materialnym a jakością życia;

- cele związane ze zrównoważeniem demograficznym rozwoju. Bardzo zbliżoną do zaproponowanej wyżej listę celów przedstawia Bogusław Fiedor:

- społeczne cele nadrzędne: dobrobyt - sprawiedliwość - bezpieczeństwo;

- cele o charakterze idealizacyjnym: wzrost realnego dochodu per capita, poprawa stanu zdrowotnego i poziomu wyżywienia, dostęp do zasobów środowiska przyrodniczego przez aktualnie żyjące i przyszłe generacje, poprawa poziomu wykształcenia,

- cele empiryczne: związane z zapewnieniem odpowiedniego poziomu różnych aktywności ekonomicznych i społecznych oraz utrzymaniem stałości zasobu kapitału naturalnego,

- cele operacyjne: reguły zarządzania zapewniające realizację celów o charakterze idealizacyjnym ${ }^{42}$.

Szczegółowy opis celów trwałego rozwoju zawiera dokument "Globalny Program Działań na Rzecz Ochrony Srodowiska i Trwałego Rozwoju "Agenda 21", co przedstawia tabela 2. Są one zbieżne z opisanymi wyżej kategoriami celów.

$42 \quad$ Podstawy..., op. cit. 
Tabela 2. Cele trwałego rozwoju w ujęciu Agendy 21

\begin{tabular}{|c|c|}
\hline KATEGORIA CELÓW & CELE \\
\hline Cele społeczne & $\begin{array}{l}\text { — zwalczanie ubóstwa } \\
\text { — zrównoważenie procesów demograficznych } \\
\text { — promocja edukacji, świadomości społecznej i szkoleń } \\
\text { — ochrona i promocja zdrowia } \\
\text { - promocja rozwoju trwałego osadnictwa } \\
\text { — ochrona różnorodności kulturowej } \\
\text { - rozwój samorządności i demokracji }\end{array}$ \\
\hline Cele ekonomiczne & $\begin{array}{l}\text { - międzynarodowa współpraca gospodarcza na rzecz } \\
\text { trwałego rozwoju } \\
\text { — zmiany modelu konsumpcji } \\
\text { - wzrost i zrównoważenie składników materialnych } \\
\text { i pozamaterialnych dobrobytu } \\
\text { - wykorzystanie zasobów i mechanizmów finansowych } \\
\text { w celu realizacji trwałego rozwoju } \\
\text { - transfer proekologicznych technologii } \\
\text { - rozwój czystej produkcji } \\
\text { - kooperacja i tworzenie potencjału rozwojowego w } \\
\text { krajach Trzeciego Świata }\end{array}$ \\
\hline Cele ekologiczne & $\begin{array}{l}\text { — ochrona jakości i dostępności zasobów wodnych } \\
\text { — } \text { ochrona mórz, oceanów, obszarów brzegowych } \\
\text { zintegrowane podejście do planowania i zarządzania } \\
\text { zasobami ziemi } \\
\text { — zwalczanie pustynnienia i suszy } \\
\text { — } \text { rozwijanie trwałości obszarów górskich } \\
\text { - promocja trwałego rolnictwa i rozwoju wsi } \\
\text { — zwalczanie wylesiania } \\
\text { — zachowanie różnorodności biologicznej } \\
\text { — proekologiczny rozwój biotechnologii } \\
\text { — } \text { ochrona atmosfery } \\
\text { - zrównoważona gospodarka odpadami, ściekami, } \\
\text { odpadami niebezpiecznymi } \\
\text { - bezpieczne postępowanie z odpadami radioaktywnymi }\end{array}$ \\
\hline Cele instytucjonalne & $\begin{array}{l}\text { - integracja polityki środowiskowej z polityką gospodar- } \\
\text { czą i społeczną } \\
\text { — rozwój badań naukowych na rzecz trwałego rozwoju } \\
\text { - współpraca na rzecz rozbudowy potencjału gospodar- } \\
\text { czego krajów rozwijających się } \\
\text { - rozwój instrumentów prawnych } \\
\text { - rozwój i szybszy przepływ informacji } \\
\text { - wzmacnianie roli najważniejszych grup społecznych }\end{array}$ \\
\hline
\end{tabular}

Źródło: opracowanie własne na podstawie dokumentu Agenda 21. 
W kontekście jego celów trwały rozwój można określić jako wielowymiarową koncepcję rozwojową obejmującą aspekty ekonomiczne, ekologiczne, społeczne i instytucjonalne. Stawia to $\mathrm{w}$ niekorzystnym świetle praktykę dotychczasowych strategii rozwoju ograniczających kwestie rozwojowe do zagadnień ściśle ekonomicznych, a przez to jednowymiarowych i niedostatecznie efektywnych.

\section{Trwały rozwój jako koncepcja wzrostu efektywności gospodarowania}

$\mathrm{W}$ wielu publikacjach poświęconych trwałemu rozwojowi pojawia się pogląd, że realizacja jego celów jest utrudniona ze względu na nadmierną fizyczną wielkość gospodarki sprowokowaną rozbudzonymi oczekiwaniami konsumpcyjnymi i nadmiernym wzrostem produkcji. Pogląd ten sugeruje konieczność ograniczenia rozwoju i wymuszenia przede wszystkim na konsumentach akceptacji potrzeby wyrzeczeń i radykalnej zmiany stylu życia, ponieważ dotychczasowy oparty był na hiperprodukcji i hiperkonsumpcji i nie da się go kontynuować w warunkach kryzysu środowiska ${ }^{43}$. Zarazem mowa o nadmiernym rozwoju wydaje się ryzykowna zważywszy, że zdecydowana większość ludzi żyjących na planecie nie osiąga nawet poziomu materialnego dobrobytu określanego jako minimum egzystencji, a wszystkie społeczeństwa świata borykają się z narastającym problemem bezrobocia ${ }^{44}$. Ponieważ rozwiązanie tych problemów stanowi jeden z celów trwałego rozwoju, należałoby go raczej postrzegać jako koncepcję wzrostu dobrobytu, a więc w pewnym zakresie kontynuację dotychczasowych ambicji rozwojowych tyle, że realizowanych $\mathrm{w}$ inny sposób i ze znacznie szerzej wielowymiarowo ujętymi celami strategicznymi. W takim rozumieniu trwały rozwój jest koncepcją wzrostu efektywności gospodarowania w jego wymiarze ekologicznym i społecznym, ponieważ dotychczasowa ścieżka rozwoju była niedostatecznie efektywna - zbyt rozrzutnie dysponowano kapitałem przyrody oraz przypisywano niedostateczną rangę społecznym aspektom gospodarowania skupiając się na wzroście efektywności produkcji, materialnie rozumianym zysku oraz równie materialnie rozumianym wzroście konsumpcji.

Na poziom życia ludności składają się: poziom konsumpcji dóbr i usług, poziom bezpieczeństwa społecznego oraz stan środowiska przy-

43 Taka opcja postrzegania trwałego i zrównoważonego rozwoju jest szczególnie popularna wśród filozofów i etyków piszących o tym zagadnieniu, np. K. WALoszczYK, Kryzys ekologiczny w świetle ekofilozofii, wyd. Politechniki Łódzkiej, Łódź 1996, rozdział III.

44 H.G. Kastenholz, K.D. Erdmann, M.WolfF, Nachhaltige Entwicklung-Zukunftschancen fue Mensch und Umwelt, Springer, Berlin 1996. 
rodniczego ${ }^{45}$. Praktyka gospodarcza większości krajów skupiona jest na tym pierwszym aspekcie nieco lekceważąc pozostałe ${ }^{46}$. Efektem tego jest generowanie nadmiernych kosztów ekologicznych i społecznych wzrostu produkcji i konsumpcji. Tym samym pewne kategorie potrzeb nie są zaspokajane, co oznacza, że proces gospodarowania jest nieefektywny.

Trwały rozwój jest zatem koncepcją rozwoju gospodarczego obejmującą całokształt elementów składających się na poziom życia, zatem nie tylko produkcję, dochód konsumpcję i akumulację, ale także bezpieczeństwo społeczne i jakość środowiska przyrodniczego. Podstawowym dylematem nie jest więc próba odpowiedzi na pytanie, jak ograniczyć produkcję i konsumpcję, lecz jak zmienić sposób funkcjonowania gospodarki, by wzrost produkcji i konsumpcji nie generował wzrostu presji na środowisko przyrodnicze i nie ograniczał poziomu socjalnego bezpieczeństwa. Chodzi o poszukiwanie form produkcji i konsumpcji, które generowałyby niższe koszty ekologiczne i społeczne, niż obecne.

Problem społecznej efektywności gospodarowania od lat jest przedmiotem zainteresowania ze strony teorii i praktyki polityki społecznej. Wydaje się, że cele trwałego rozwoju są $\mathrm{w}$ tym aspekcie zbieżne $\mathrm{z}$ celami tej polityki. Dlatego teoria trwałego rozwoju więcej miejsca poświęca problemowi efektywności gospodarowania w jego wymiarze ekologicznym.

Strategicznym celem trwałego i zrównoważonego rozwoju jest zachowanie takiego stanu środowiska przyrodniczego, który nie zagrażałby funkcjonowaniu gospodarki. Funkcje określające ekologicznie uwarunkowane możliwości rozwoju społeczno-gospodarczego są najczęściej przedstawiane $\mathrm{w}$ postaci modelu gospodarki okrężnej. Obejmuje on trzy podsystemy:

— podsystem "gospodarka", obejmujący produkcję dóbr konsumpcyjnych, dobra konsumpcyjne, użyteczność opisującą poziom dobrobytu oraz recykling;

- podsystem „środowisko przyrodnicze" obejmujący zasoby naturalne, w tym odnawialne i nieodnawialne oraz odpady, a także zdolność asymilacyjną środowiska, stopę regeneracji zasobów i stopę ich eksploatacji;

— podsystem „społeczeństwo" obejmujący świadomość społeczną wspartą przez instytucje i organizacje społeczne, który wywiera wpływ na relację między gospodarką a środowiskiem oraz jest przez nie współkształtowany.

45 Teoria ekonomii. Makroekonomia, red. K. Meredyk, wyd. Uniwersytetu w Białymstoku, Białystok 1998, s. 221

46 Nawiasem mówiąc, wiele podręczników makroekonomii sankcjonuje tak ograniczone rozumienie kwestii rozwojowych. 
Zasoby i energia zużyte $\mathrm{w}$ gospodarce tworzą $\mathrm{w}$ sferze konsumpcji użyteczność będącą miarą dobrobytu $\mathrm{w}$ takim stopniu i o takiej strukturze, jakie wypływają z uwarunkowań społecznych. Zarazem przekształcają się one w odpady i zanieczyszczenia. Środowisko przyrodnicze jest rezerwuarem przyjmującym te odpady i zanieczyszczenia. Część z nich można przywrócić za pomocą recyklingu gospodarce pod warunkiem, że koszt ich powrotu jest niższy, niż koszt pozyskania nowych zasobów tego samego rodzaju. $W$ przypadku pozostałych odpadów i zanieczyszczeń ich oddziaływanie jest różne w zależności od pojemności asymilacyjnej środowiska. W sferze zasobów odnawialnych skutki procesów gospodarczych zależą od relacji między stopą ich odtworzenia i stopą eksploatacji. W przypadku zasobów nieodnawialnych ich ilość ulega stałemu zmniejszeniu, natomiast $\mathrm{w}$ przypadku odnawialnych jest zmienna. Tym samym fizyczne rozmiary gospodarki są ograniczone przez możliwości asymilacyjne środowiska przyrodniczego, co oznacza konieczność spełnienia warunku opisanego przez wzór:

$$
W<A \text {, }
$$

gdzie $W$ oznacza wielkość zrzutu odpadów, a $A$ zdolność asymilacyjną środowiska;

oraz przez zdolność regeneracyjną zasobów odnawialnych, z której wynika spełnienie warunku wyrażonego przez wzór:

$$
h<y \text {, }
$$

gdzie $h$ oznacza stopę eksploatacji zasobów odnawialnych, a y stopę ich regeneracji.

Nie są to wszak jedyne ograniczenia.

Systemy ekologiczne nie stanowią całkowicie zastępowalnego czynnika produkcji dóbr konsumpcyjnych, ponieważ spełniają rolę bezpośrednio konsumpcyjną, której substytucja, być może realna, nie jest akceptowalna społecznie. Ranga zasobów środowiska jako dóbr konsumpcyjnych jest zależna od charakteru relacji między środowiskiem przyrodniczym a społeczeństwem, przede wszystkim upowszechnionym typem świadomości społecznej.

Kolejnym ograniczeniem jest konieczność spełnienia wymogu sprawiedliwości międzypokoleniowej. Oznacza ona, że maksymalizacja użyteczności danego podmiotu $\mathrm{w}$ danym punkcie czasowym jest ograniczona warunkiem utrzymania przez niego tego poziomu we wszystkich przyszłych okresach, a także swoich poziomów przez pozostałe jednostki w ramach całego przyjętego horyzontu czasowego.

Tak więc zasoby i walory środowiska stanowią dobra ekonomiczne, ograniczone ze względu na:

- ograniczone możliwości asymilacyjne środowiska,

- ograniczone zdolności regeneracyjne zasobów odnawialnych,

- bezpośrednią konsumpcję dóbr środowiskowych,

- konieczność respektowania sprawiedliwości międzypokoleniowej. 
Tym samym powinny one być traktowane jako element ograniczonych zasobów gospodarczych, posiadać wartość, a rynek powinien określać ich cenę. Zagrożenie degradacją środowiska naturalnego pojawia się wówczas, gdy jakiś składnik przyrody wcią̇ traktowany jest jak dobro wolne, a tymczasem dobrem wolnym już nie jest. Podnosi to sztucznie poziom rezultatów działalności gospodarczej, natomiast zaniża koszty wytwarzania- a więc stwarza złudzenie wysokiej efektywności tam, gdzie ta efektywność jest w rzeczywistości dużo niższa (...). Wynika stad, że niedoszacowywanie, czy też wręcz pomijanie wartości zasobów naturalnych w rachunku kosztów może stać się źródłem pozornej nadwyżki ekonomicznej, a więc ma być przyktadem emitowania przez system gospodarczy błędnych sygnatów. Dtugotrwate istnienie takiej sprzeczności okazuje się jedynie kredytem zaciagniętym w banku noszacym nazwę środowisko naturalne ${ }^{47}$.

W jaki sposób poprawić efektywność gospodarowania zasobami środowiska - ten problem jest przedmiotem kontrowersji wśród ekonomistów środowiska. Zwolennicy ekonomii środowiskowej proponują urynkowienie zasobów na tyle, na ile jest to możliwe zakładając, że rynek stanowi najlepszy instrument alokacji ${ }^{48}$. Natomiast zwolennicy ekonomii ekologicznej uważają raczej, że należałoby wyznaczyć pewną nieprzekraczalną w jakiś sposób administracyjnie narzuconą granicę ingerencji gospodarki w środowisko przyrodnicze ${ }^{49}$. W praktyce wykorzystuje się instrumenty reprezentujące oba typy myślenia o relacji "gospodarka - środowisko", co oznacza, że oba ujęcia należy traktować jako komplementarne. Być może złożą się one w przyszłości na kompleksowe niesprzeczne ujęcie ekonomii środowiska i zasobów naturalnych.

Fizyczne rozmiary gospodarki są zatem ograniczone. Ponieważ współczesny kryzys ekologiczny świadczy o przekraczaniu tych granic, niezbędne wydaje się równoczesne podjęcie dwóch kategorii działań.

Przede wszystkim konieczna wydaje się rewolucja efektywności gospodarowania wspierana umiejętnym urealnieniem kosztów ekologicznych procesów produkcji i konsumpcji. Publikacje naukowe wskazują na znaczne możliwości w tym zakresie, że możnaby zużywać cztero- a nawet dziesięciokrotnie mniej zasobów, by uzyskać ten sam efekt konsumpcyjny ${ }^{50}$. Przy tym rysuje się nieco odmienna strategia działania w krajach wysoko rozwiniętych i krajach rozwijających się.

47 Teoria ekonomii. Tom I Mikroekonomia, red. K. MeredyK, Wyd. Uniwersytetu w Białymstoku, Białystok 1998, s. 43-44.

48 Por. np. R.M. Solow, Intergenerational Equity and Exhausible Resources, „Review of Economic Studies"1974, s. 29-45; także B. FIEDOR, Przyczynek do ekonomicznej teorii zanieczyszczenia i ochrony środowiska, Ossolineum 1990.

49 Ecological Economics...op. cit.

50 E.U. von Weizsacker, A.B. Lovins, L.H. Lovins, Mnożnik cztery. Podwojony dobrobyt- dwukrotnie mniejsze zużycie zasobów naturalnych, wydawnictwo Rolewski, Toruń 1999. 
W krajach wysoko rozwiniętych uzyskany został wysoki poziom dobrobytu materialnego okupiony potężną degradacją środowiska przyrodniczego spowodowany stosowaniem nadmiernie środowiskochłonnych technologii przemysłowych. Podstawowym dążeniem w ramach trwałego rozwoju jest utrzymanie a nawet wzrost dobrobytu przy jednoczesnym przeorganizowaniu gospodarki polegającym na radykalnym zmniejszeniu materiałów i energochłonności procesów produkcji i konsumpcji, czyli na ich odmaterializowaniu. Chodzi więc o poszukiwanie nowych, odmiennych form produkcji i konsumpcji w tym wykorzystanie już istniejących trendów zmian $\mathrm{w}$ tych procesach. Natomiast problemem krajów rozwijających się jest poszukiwanie takich ścieżek rozwojowych, które umożliwiłyby osiągnięcie wzrostu dobrobytu przy uniknięciu tak silnego wzrostu presji na środowisko, jak to miało miejsce w przypadku krajów wysoko rozwiniętych. Wyzwaniem jest tu także przeciwstawienie się sytuacji obecnej tych krajów, w których szybka degradacja środowiska przyrodniczego $\mathrm{w}$ bardzo ograniczonym stopniu przekłada się na wzrost dobrobytu jako, że zasoby naturalne tych krajów przeznaczane są w znacznej mierze na zaspokojenie potrzeb konsumentów z krajów wysoko rozwiniętych. Chodzi więc o to, by kraje rozwijające się uniknęły tradycyjnego modelu rozwojowego charakteryzującego się nadmierną presją procesów produkcji i konsumpcji na środowisko przyrodnicze.

Opisana rewolucja efektywności gospodarowania w wymiarze ekologicznym nie ogranicza się tylko do zmian w gospodarce, czyli do przemian $\mathrm{w}$ procesach produkcji i konsumpcji, ale odnosi się również do funkcjonowania społeczeństwa. Wymaga ona bowiem określonego stosunkowo wysokiego poziomu cywilizacyjnego i szczególnego charakteru świadomości społecznej. Stąd wynika kolejne zadanie związane z koncepcją trwałego rozwoju. Chodzi o zmianę preferencji producentów i konsumentów. Istotne znaczenie odgrywać tu będa:

a) przesłanki techniczno-ekonomiczne (infrastruktura techniczna, kondycja ekonomiczna przedsiębiorstw, regulacje prawno-administracyjne, podatkowe itp.),

b) uwarunkowania społeczno-polityczne (ogólny poziom wykształcenia, stan świadomości ekologicznej społeczeństwa, postawa i interesy znaczących - w sensie decyzyjnym - grup w obrębie tak zwanej klasy politycznej),

c) czynnik i regionalne i globalne (wspótpraca międzynarodowa, dostępność do stosownych technologii, fluktuacje rynków finansowych itp. $)^{51}$.

Jakie więc instrumenty mogą umożliwić wdrożenie trwałego rozwoju - przede wszystkim innowacje oraz rozwój sił wytwórczych (inwestycje w zasoby pracy).

51 Z. Hull, Rewolucja efektywności, „Człowiek i Przyroda” 1999/2000 nr 11-12, s. 110-111. 
Z powyższych rozważań wypływa zatem wniosek, że perspektywy trwałego rozwoju w skali globalnej zależą głównie od tego, na ile i w jakim tempie możliwy będzie wzrost ekologicznej i społecznej efektywności produkcji i konsumpcji, a w krajach średnio rozwiniętych i krajach Trzeciego Świata również przełamanie opóźnienia cywilizacyjnego, które jest warunkiem niezbędnym modernizacji ich gospodarki $\mathrm{w}$ takim kierunku. $\mathrm{W}$ innym przypadku niemożliwe będzie odejście od tradycyjnych uciążliwych dla środowiska form gospodarki. Warunkiem niezbędnym trwałego rozwoju są inwestycje w kapitał ludzki, poprawa poziomu wykształcenia, wzrost wynalazczości i innowacyjności. Trwały rozwój nie oznacza więc stagnacji, a przeciwnie, przyspieszenie procesów rozwojowych.

Powyższa konkluzja bliska jest ujęciu procesów rozwoju społecznogospodarczego $\mathrm{w}$ ramach teorii wzrostu endogenicznego i zdaje się potwierdzać twierdzenie ekonomiczne przyjmujące, że zasoby przyrody spełniają istotną, lecz bierną rolę $\mathrm{w}$ gospodarce, natomiast podstawowym czynnikiem rozwoju jest kapitał ludzki.

\section{Zakończenie}

Trudny do utrzymania wydaje się dominujący w polskiej literaturze pogląd utożsamiający trwały rozwój z ekorozwojem, czyli rozwojem społeczno-gospodarczym dostosowanym do możliwości środowiska przyrodniczego. Należałoby tę kategorię postrzegać w sposób całościowy, w rozumieniu którego zrównoważenie gospodarki ze środowiskiem przyrodniczym ma znaczenie instrumentalne służące zachowaniu nieograniczonych możliwości rozwoju społeczno-gospodarczego i szerzej rozumianego rozwoju cywilizacyjnego ludzkości. Podstawowym celem trwałego rozwoju jest bowiem zapewnienie wzrostu dobrobytu społecznego rozumianego wszak znacznie szerzej, niż w tradycyjnym rozumieniu tego pojęcia - jako odpowiednią proporcję między poziomem materialnej konsumpcji oraz poczuciem bezpieczeństwa ekologicznego i społecznego ludzkości. 


\section{What does it mean: permanent development?}

\section{STRESZCZENIE}

Tematem artykułu jest próba sprecyzowania kategorii trwałego rozwoju jako całościowej koncepcji rozwoju społeczno-gospodarczego i szerzej rozumianego rozwoju cywilizacyjnego. Artykuł polemizuje z często spotykanym w polskiej literaturze przyrodocentrycznym rozumieniem tej kategorii sprowadzającym do trwałego rozwoju jedynie do zrównoważenia ekologicznego gospodarki. Trwały rozwój należałoby raczej postrzegać jako koncepcję rozwojową, w której dąży się do zapewnienia odpowiedniej proporcji między poziomem materialnej konsumpcji oraz poczuciem bezpieczeństwa ekologicznego i społecznego ludzkości. Takie rozumienie trwałego rozwoju wynika z jego uwarunkowań ekologicznych, społecznych, politycznych, teoretycznych i filozoficzno-etycznych, a także $z$ interpretacji proponowanych definicji tej kategorii oraz teoretycznych i normatywnych („Agenda 21") kategoryzacji jej celów.

Trwały rozwój można uznać za koncepcję wzrostu efektywności gospodarowania w jego aspekcie ekologicznym i społecznym. Drogą do poprawy efektywności są nie tylko procesy gospodarcze ujmujące realne koszty oraz korzyści ekologiczne i społeczne podejmowanych działań gospodarczych, ale także kształtowanie świadomości i humanizmu ekologicznego. 